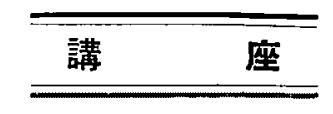

\title{
遷音速風洞の概観 (1)
}

\section{目次}

1. 要音速風洞の発展と原理

2. 透音速風洞の種類々現状

3. 一棦称音速流生成

4. 僄音速風洞壁干渉の理論

5. 遷音速風洞壁干逤の実験

\section{1. 要音速風洞の発展と原理}

徉来の風洞が choking の現索起すので，この解 決はすでに 15 年む以前から緊急の問題ですった. 一 方実際の飛行機は音速を過って shock stalling にた

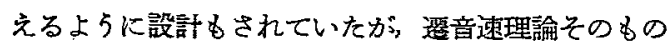
は结とんど何名知られていなかった，choking の限界 のために風洞が使えないので，我行実験などによる研

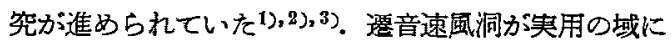
達したのは 1950 年前後のことで，それは測定部の壁 を過ぎって彥流の一部を通風室に導き，次いで外人導 かれた空気を拱散筒の入口で何らかの ejector の作用 によって再び吹き边さか，または風路の適当な場所に 譏械的圧縮によって扟し迈むことに上って要音速流を 作ることがでる上らになったためである. その際に

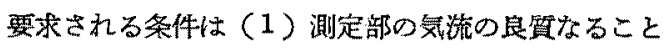
(2) 最小の馬打で斉ま妪こと（3）作動力簡単で あること（4）建設が容易であることなどである. 澄 音速風洞は同じ大きさの従来の風洞に必要な動力の外 に更に壁から技けた気流が受ける運動エネルギーの椇 失を回復するに要するだけの動打を付加せ小ばならな い. 音速では大したことはないが音速を超えると急に 補助動力が堌すので， $M=1.25$ 以下で用い, ラバル 管を併用する方法子考えられたが条り実用されず，ま た作動は主倛動系統の制微のみによる方法が背通とな $っ て い る$.

始めに㖶音速虫洞を完成したのは NACA, Langley Aero. Lab. の John Stack である. 1928 年から 31 年にわたって開虫洞と閉風洞とを比皎して choking

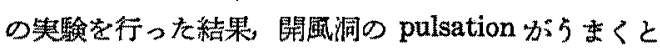

\footnotetext{
*東京大学理工学蛑筧所
}

れれば $M$ 数 1.0 までの実験が可能でむることがわか り，開風洞と閉呱洞の中間の風洞を作ればよいといら 概念を確立した. 一方 Wright') (理論的に blockage interference を除く可能性を示し，非正縮の場合 に干渉を零にすれば，生縮性を考穴てる同様に干涉を 零にすることができことを示して, choking を取除 くための理論的根妓を与えた。 1945 年 6 月に $8 \mathrm{ft}(M$ 数 0.8) そ $16 \mathrm{ft}(M$ 数 0.7) 0 㼙洞の黑力增加力決 定し，1945 年に $8 \mathrm{ft}$ の国洞を 18,000P に增加して $M$ 数 0.95 京での笑験え成功した. 同時に半開風洞に 上って低超音速流を作る可能性も考六 5 丸，理掄的根 技は余り確荑ではなかったが，1946 年に惊 $16 \mathrm{ft}$ の 風洞の馬打增加る 行に移されることとなった. 1948 年には小さい風洞によって測定壁の理論る確認されい よいよ最終工事に脚って 1950 年 4 月 $8 \mathrm{ft}$ の完全な 要音速風洞が完成，次いで 1950 年 12 月 $16 \mathrm{ft}$ の風 洞与作動人入った. NACA の有满壁に上る遥音速風 洞の成功にならって Cornell Aero. Lab. では 81'x $12^{\prime}$ の变正風洞の改装に着手することになった. 主動 力か限定されていたことや，超音速流を出すためには 風洞の長さか短かすぎたことなどを解決するために Goodman ら方汧究を行った結果，特に一様な超音速 流を作り，また反射波を吸収するという点から見て有 孔壁の優れていることか証明され，したがって補㽖動 力禾統をつけることの方針む樹てられた。まず 1950 年 10 月の成功についで，その後有孔壁の本格的研 究193, 20)に入り, Goethert \& Taylor, Pindzola, Maeder, Gardinier らの協力を得て 1952 年 10 月に は $3^{\prime} \times 4^{\prime}$ の僄音速風洞を既に運転を開㕸寸るに至っ $\hbar^{212,23)}$. 次に米室軍力弾後 WADC に脌った $10 \mathrm{ft}$, 40,000 EP の造意速風洞について記す，第 1 図に示す 如く四周に沿って 8 本の絽溝安開け，超音速流を作る 際の過膨脹を避けるために有孔板でその满を掩ってい る. 侧壁の一部をかたもけて断面稳の制御がてさる最 大吸出量的 $9 \%$ をとれる補助動力を有し，吸出された

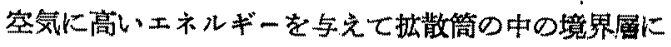

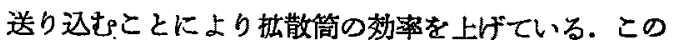
風洞は超音速に括いて波の吸収特性が要い上5であ 

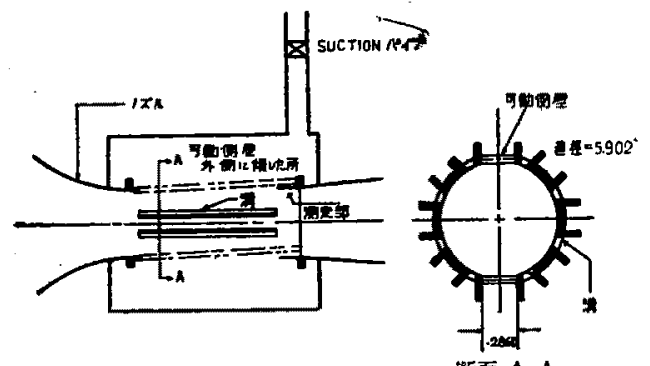

断面 A-A

第1図有孔板で掩われた有灌壁をるつ僄音 速風洞

る. Boeing では NACA での成功の直徏, 1948 年 から $1 / 20$ の大いるの模型風洞によってまず改良を始 め, 従来の $8^{\prime} \times 12^{\prime}$ の風洞の duct の長さを $9 \mathrm{ft}$ 增加 し， 18,000 P の同期電㫪機に $36,000 \mathrm{PP}$ の誘導電動 機を接続することによって，M 数 1.2 まで得られる 私有と乙て结世界最大の要音速風洞を完成した。この 風洞は補助動力系統を用いず，有满壁を通って出を空 気は，Boeing 独特の再導入用フラップによって拡散 筒の中に痛るようになっているのだ，搪散筒の効率も 良い上5でする。最後に世界最大の遷音速風洞が空軍 の AEDC K米国の Unitary plan k基いて起工品 れ，1955 年に完成することになっているが,この風洞 の建設のための計画に参加した施設並びに委員の名を 参考のために記して置く。

Special Committee: ARO, Ine. (B.H. Goethert, Chairman, H. E. Gardinier, Recording Secretary) Boeing, Inc. (W. Huntington), Brown Univ. (P. F. Maeder) C.A.L. (A.H. Flax). NACA Langley (I.G. Recant) SCCWT (J. E. Smith). Sverdrup \& Parcel, Inc. (M. Pindzola) UAC (H. Taylor).

上記の如く，特に米国の風洞は馬力の増加を行って 票音速風洞として改装することに始まり，上うやく現 在のような段陵に羍したのであって，今後全く新規に 覆音速風洞を建設するという場合には良来の経験を生 かすととすに新しい偝計によってきわめて性能の優れ たものも作り得る可能性が大いにるることに注意した い.

\section{2. 音速風洞の穗類と現状}

要音速流を風洞中に作るには多くの方法が考えら九 ているが，最す普通には有溝壁と有孔壁の方法が用い られている. 有藏壁の方法とい5のは主流の方向に鄚 に满を掘って主洗の一部を通風空に導き，外に出在気 流を再び抬散筒の入口に运く方法である.この方法で は吸出すをめの㭪助動力は普通には用いていない（第 2 図).これに対して有孔壁の方法というのは一般に ちる一定の大きさを有する沢山の孔を測定壁に開ける

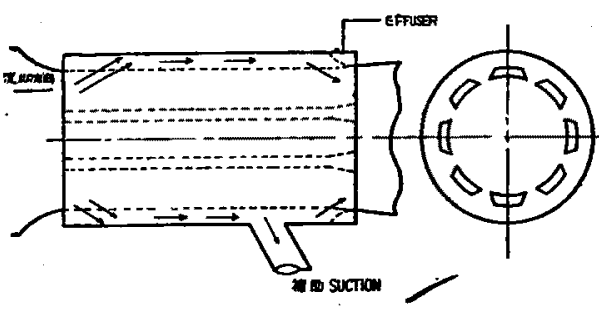

第 2 图代表的な有等壁風洞

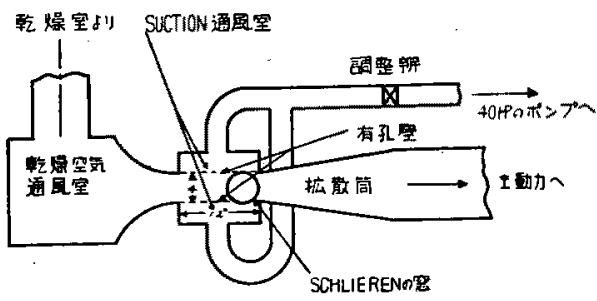

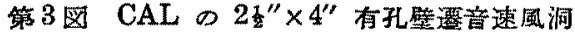

方法で，測定壁を過ぎるときに運動のエネルギーを失 って総生損失をとむな5ので，補助動力を用いて吸出

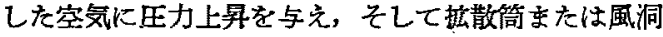
のダクトの広い面積を有する部分に，再び導入する方 法である. 第 3 図はその 1 例を示す. 第 3 の方法は, “Twin-stream”法といって始め英国の Kuchemann によって称えられ，これとは独立に米国では United Aircraft Co-operation の人々によって研究された.

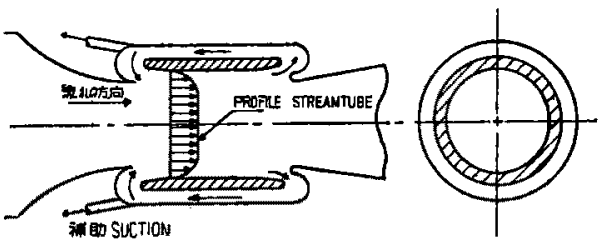

第4図 Profile stream 法に上る㟟音速風洞

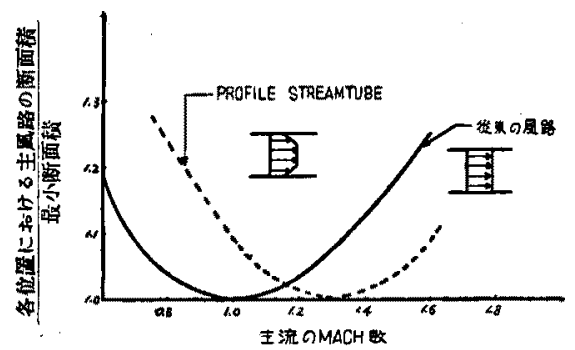

第 5 圆 Profile stream 法 $\varepsilon$ 固定壁風洞 の choking 特性の比較

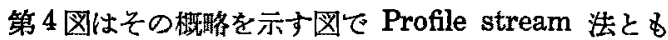
いわれ，低速の流れの周にかこまれた高速の流れを測 定部として使らすので，低速流層を作るのに最もよい 方法は図に示す如くなるべく総圧損失のないよ 
環させることで，主流に超音速の流れを作ることも容 易でめる。第 5 図は主流と低速流層の高さの割合を変 えることによって最高の $M$ 数を変えることができる ことを示している. しかしこの方法では超音速流にお ける反射波の吸収といら闍題を解洪することができな い.これに対して主流の外を取巻く屏を主流上りも更 に高い $M$ 数の超音速流とする方法も考光られ，これ らを棇称してわれわれは sandwich flow type の方法 と呼んでいる.

次に現存する風洞の要目括上び特に明らかにされて いる点を列記して置く.

最後に逼音速風洞の代表的なものとしてわれれれの 考えている一つの型の風洞を第6図によって説明する と，第 6 図aは音速以下に怙いて用いられる場合で㧓 散筒の中は至る所亜音速であるが，第 6 园 b は超音速

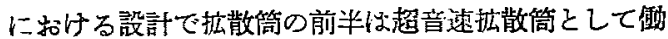

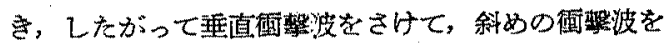
作るように設計され，しか子亜音速拡散筒の効率を下 げない上らに注意が払われている。

\section{3. 一模な基速流の生成}

模型を入える前に一様な跋音速流場を作り出すこと に注目して測定部を考えることにする．始めに有㴖壁 を用いた一例として Wright と Wardにより NACA Langley で 12 in の円形風洞を用いて行なわれた央 験を示す．第7図に示す如く流れの方向に 8 本の溝を 設けを.これは Blockage interference を零にする よらに設計されたもので溝の幅は全周の $1 / 8$ にとられ
主要風洞の要目表

\begin{tabular}{|c|c|c|c|}
\hline 所在 地 & 测它教古度 & 票 力 & 毇 \\
\hline $\begin{array}{l}\text { NACA } \\
\text { Langley }\end{array}$ & $8 \mathrm{ft}$ dia & 16,000 & $\begin{array}{l}\text { Preasure Tannel } \\
M=0.97 \sim 1.00\end{array}$ \\
\hline $\begin{array}{l}\text { NACA } \\
\text { Langley }\end{array}$ & $16 \mathrm{ft}$ dia & $\begin{array}{l}16,000 \text { を } \\
60,000 \text { に } \\
\text { 数む }\end{array}$ & 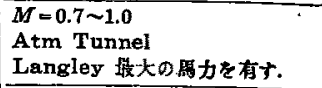 \\
\hline $\begin{array}{l}\text { Boeing } \\
\text { Seattle }\end{array}$ & $8 \times 12 \mathrm{ft}$ & 54,000 & 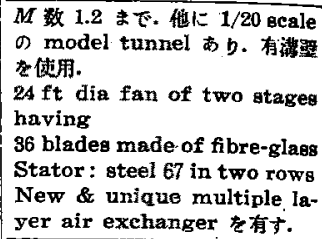 \\
\hline $\begin{array}{l}\text { C.A.L. } \\
\text { near } \\
\text { Bufflos }\end{array}$ & $3 \times 4$ ft & 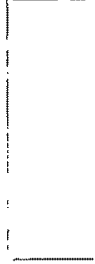 & 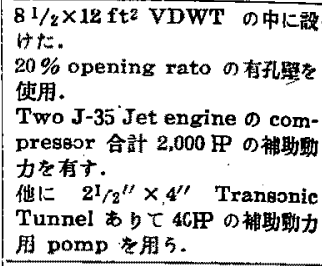 \\
\hline $\begin{array}{l}\text { WADC } \\
\text { Dayton } \\
\text { Ohio }\end{array}$ & $10 \mathrm{ft}$ & 40,000 & $\begin{array}{l}\text { 他に transonie model tun- } \\
\text { nel あり. }\end{array}$ \\
\hline AEDC & & & $\begin{array}{l}M=0.8 \sim 3.5 \text { 新役 } \$ 170 \mathrm{mil}- \\
\text { lions. }\end{array}$ \\
\hline $\begin{array}{l}\text { Tull, } \\
\text { Tenn. }\end{array}$ & $16 \times 16 \mathrm{ft}$ & $\begin{array}{c}216,000 \\
k \\
400,000 \\
k=0200\end{array}$ & 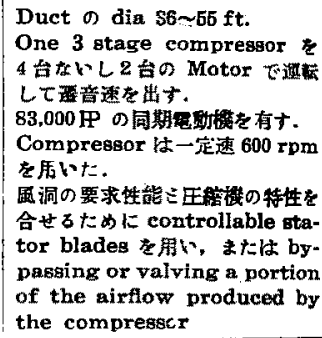 \\
\hline
\end{tabular}

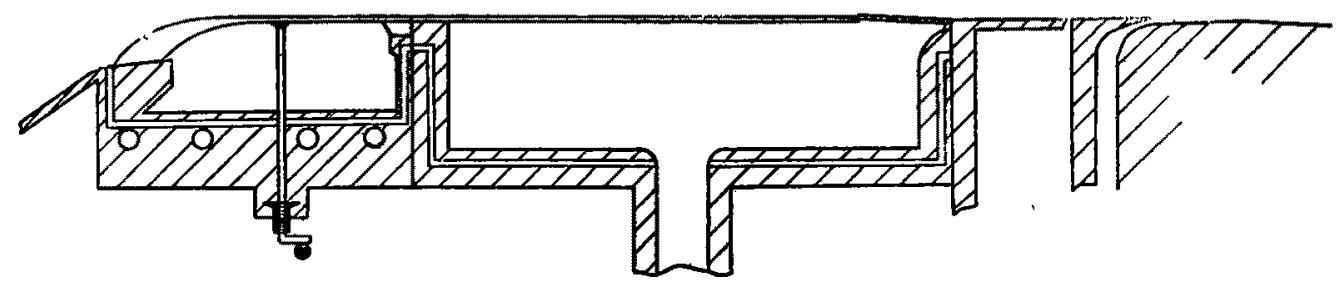

(a)

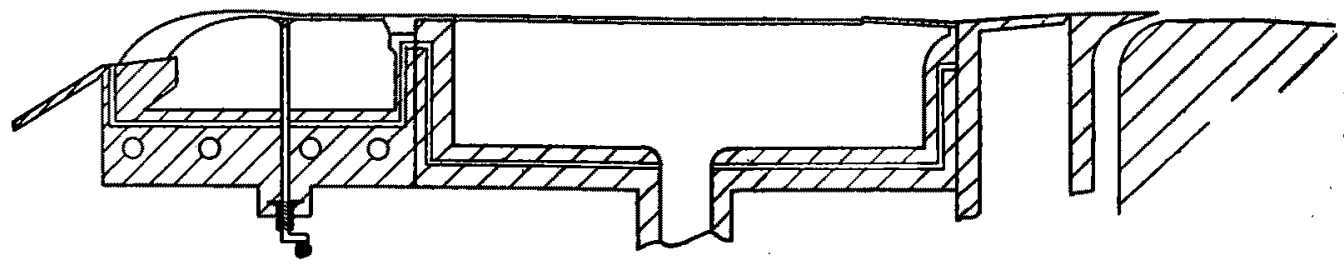

第6图（b) 

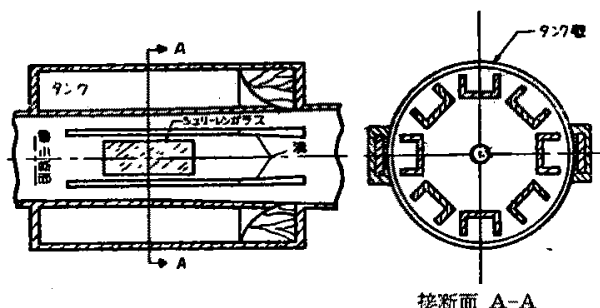

第 7 図 有灌壁栭洞の 1 例

た. 測定部では溝の幅を一定とし，下流の掘散筒の中 では断面積も溝の幅す $20 \%$ 增しとし，この位置では 外側に图に示寸如く effuser bell がついている.一 度通風堂に出た気流は再び㧨散筒の中に導入されるよ らになっており，超音速の場合に仿 effuser bell の出

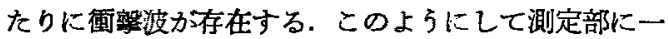
様な $M$ 数の分布を得ることができたか，特に超音速 に怙ける $M$ 数の一样な部分の長さは直径の半分ぐら いしかないよらである。

有孔壁についての風洞特性を次に述へ上弓，理想流 体を考える限り $M:=1$ までは suction を行う必要は ないことになるが，实際には測定部に王力降下゙現わ れ，通風空の静生は気流の前方の静里よりは低く，主流 の下旅の静王よりは高いといら結果になる．乙たがっ て測定壁の前方では気流は外側の通風害に漏九出すこ とになり，交下流では流れ込んで来ることになる。 下流部分で流九边む流体の総圧位下しているので, 主流の压排下はそのために更に大きくなる.かくし て測定部の下流部分に $M=1$ になる所ができて, 主 流を choke させることになるのだこれをさけるた めに通風車からの suction が必要になってくる。この ことを㜔界層の立場で考えると，有孔壁は普通の滑か な壁よりも表面わ浣く，また流れ出寸気流のために壁 には大きな剪断力を生ずるよらな流場分布になるの で，境界屬の厚さだけはどらして娄四出してやらねば ならぬ. suetion の量を決めるために簡単な理論計算 をすることができる.すなわちまず choking が起る 場合の境界尿の厚さ规唯にとって；これから境界層 の非除厚を求めて下流に向って断面積の縮小する割合 を決め，次に一次元の連続の関係から，この断面積の 縮小にかかわらず澌定部に沿って一样なM数分布が淂 られるために，四出されねばならない空気量を計算す る. 音速に抬ける实際の suction の量怯主流の約 $5 \%$ 程度である. 超音速流を作るためには主流を膨脤させ る必要があるので， suction は絶対に必要な条件であ る. suction は事英滛音速栭洞の速度制御の方法と乙 てもをた封に馬力を節約する点から見てもきかめて雾 れた方法であることは別の所です述へる通りである.

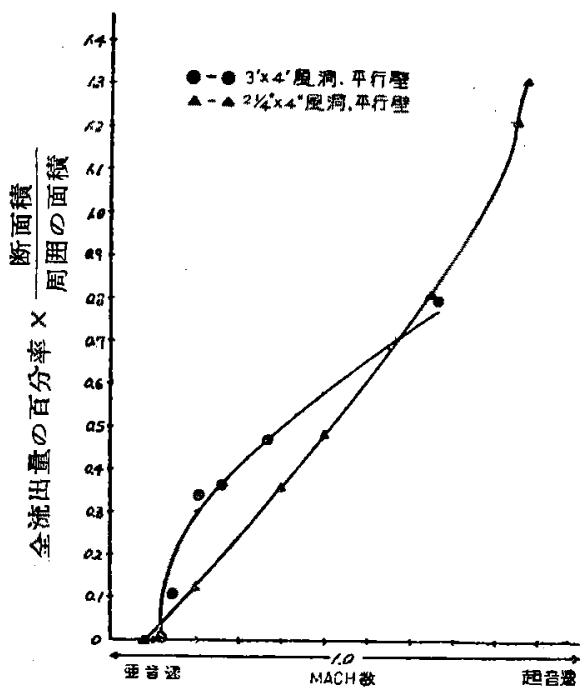

第8図 $M$ 数と流出雷の関俉

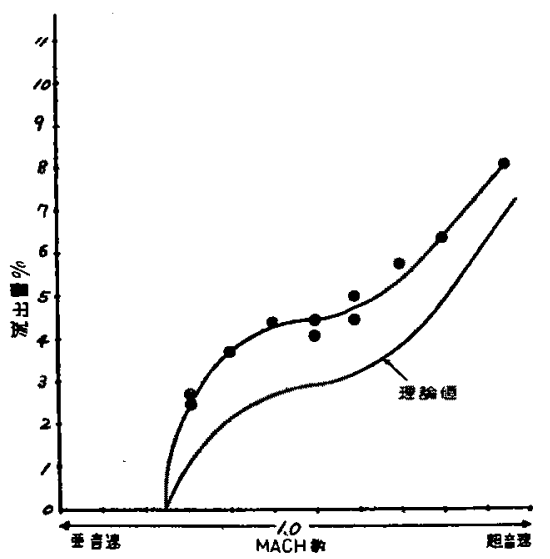

第9图 $15^{\prime}$ 搪げた有孔等の流出量に対する 実臥と瑅論の比校

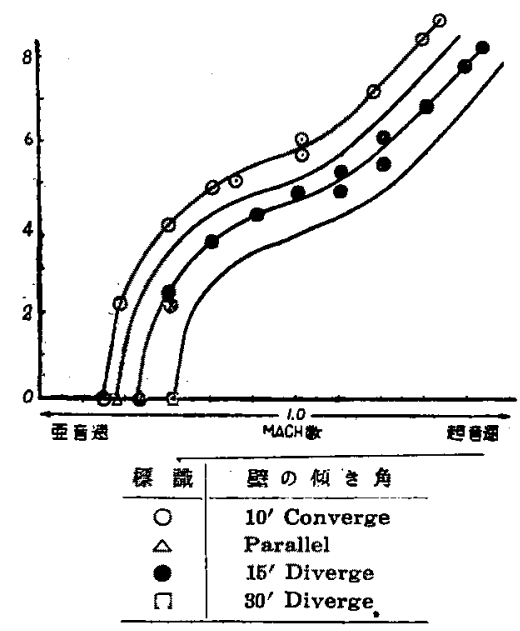

第 10 四壁の傾き角と流出量との関保 
第 8 図は寸法の異なる二つの唒洞でいずれも平行壁を 用い方場合の実験結果である。第 9 図に示寸如く理想

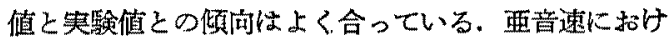
る suctionの量が少いはど理論仁近い值が得られる。 境界層の排除厚は $M$ 数によって異なるし，また壁を 通って気流が谓大するために境界層の厚さは变ると考 えられ，更に主流の方向に沿っての $M$ 数の分布に不 規則性が劣れば，それだけ気流の出入を增すので，し たがって suction の量も增えてくる．第10図に示す ように壁を 15 ないし 30 分ぐらい払げを方がよい上 うである. $M$ 数が高くなると主流の $M$ 数分布が波を 打って一様ではなくなる傾向がるるが，これは壁を 1 度以内で幾分抬げることによってかなり改善される。 乙か乙，この場合に境界層は厚くなるので実際に模型 を入れた時の反射波の吸収といら点から見るとかえ。 て具合が悪い，主流の境界層をでるる゙け䔦くし，木 た孔を通る際の抵抗を增せばよいわけでするがする り極端にやると，本来の目的に沿わなくなって具合が わるい. 第 11 図の図は open ratio 5 ないし $35 \%$

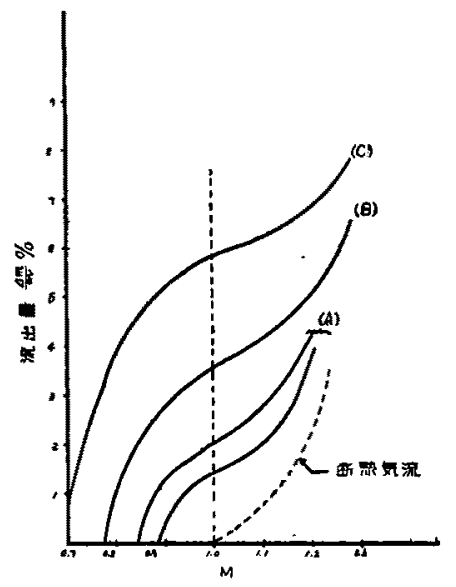

5 万至 35\%の open-ratio

(A) small opening ratio

(B) medium opening ratio

(C) large opening ratio

第 11 図 Open ratio亡流出量との関保

の有孔壁に対する suction の量の大きさを示したす のでする. 有孔壁を用いた場合の測定部の主流の状態 を一次元の線型理論を用いて記述して見よう，境界展

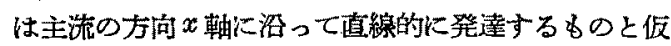
定すると主流の断面積の分布は

$$
A=A_{0}-8 \frac{d \delta}{d x} d x
$$

と表わせる．連続の方程式は

$$
\left(1-M^{2}\right) \rho A d u=\rho v s d x
$$

ただし 8 は測定壁の断面の全周長を表わす.
有孔壁における条件は porosity factor $R$ を導入 して

$$
v=\frac{R\left(p-p_{c}\right)}{\rho u_{0}}
$$

と表わす，ただし $p$ は主流の静王， $p$ 。蛙通風堂の静 压， $u_{0}$ は主流の速度を表わす，主流の择動項を $u^{\prime}$ と すると

$$
p=p_{0}-\rho u_{0} u^{\prime}
$$

ここで $p_{0}$ は主流の総王である，上の条件式を連続の 式に代入乙て線型理論の仮定で整理すると

$$
\begin{aligned}
& \left(1-M^{2}\right)\left(A_{0}-\frac{d \delta}{d x} d x\right) \frac{d u^{\prime}}{d x}-\left(s \frac{d \delta}{d x}+R s\right) u^{\prime} \\
& =s\left[\begin{array}{cc}
u_{0} \frac{d \grave{b}}{d x}+R & p_{c}-p_{0} \\
u_{0} & \rho
\end{array}\right]
\end{aligned}
$$

$x=0$ で $u^{\prime}=0$ そして稫分すると

$$
\begin{aligned}
u^{\prime}=\frac{u_{0}\left[\frac{d \grave{d}}{d x}+\frac{R\left(p_{0}-p_{0}\right)}{\rho u_{0}{ }^{2}}\right]}{\left(\frac{d \grave{0}}{d x}+R\right)} \times \\
\times\left[\left(\frac{A_{0}}{d \dot{d} x}\right)^{\frac{\frac{R}{d \delta}}{d-M^{2}}}-1\right]
\end{aligned}
$$

上に得られた結果を固定壁 $R \equiv 0$ の場合と比較する と，固定壁では $1 /\left(1-M^{2}\right)$ 乘にしをがって $u^{\prime}$ が変 化するのに対して，有孔壁では $\{1+R /(d \delta / d x)\} /(1$ $\left.\left.-M^{2}\right)\right\}$ 乘に比例して变化するので，主流の速度分布 の総変化量力限られている点を考え合せれば，固定壁 上りも一栐性の上い主流の速度分布为得られ互音速流 の $M$ は下流の部分でのみ急に変化が起ることがわか る.このことは第 12 図の実鈋によって確䖵されれる。

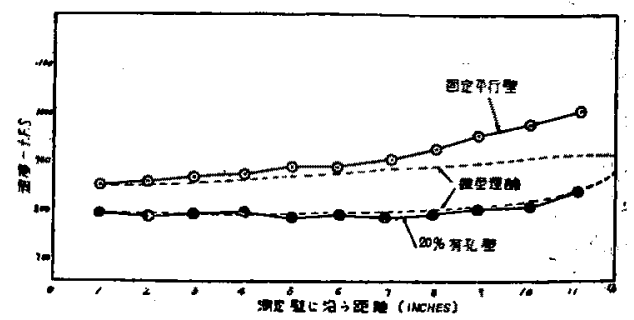

第 12 四有潡壁と固定壁との C.A.L. $21^{\prime} \times 4^{\prime}$ 風洞に上って德られた速度分布の比较

次に $d \delta / d x=0$ で，乙かも平行な壁とすると

$$
\left(1-M^{2}\right) A_{0} \frac{d u^{\prime}}{d x}-R s u^{\prime}=s \frac{R}{u_{0}} \frac{p_{c}-p_{0}}{\rho}
$$

これを稫分すると

$$
u^{\prime}=\frac{p_{c}-p_{0}}{\rho u_{0}}\left[e^{-\frac{n}{1}-\overline{M^{2}}} \frac{s}{a} x-1\right]
$$


これから

$$
v=\frac{R}{\rho u_{0}}\left(p_{0}-p_{c}\right) e^{\frac{R}{1-M^{3}} \div A}
$$

か得られる.上の式を見ると測定壁が平行であるとし て主流が重音速の場合には漏洩速度は下流部分で大き くなり，超音速の場合には逆に上流部分で大きいこと がわかる. まを外から流れ达さ产流は運動エネルギー を失って総生が主流の静王と同じ伯になっていること を考慮すると porosity factor は2 倍になるという結 果か得られ，乙たがって同じ測定壁に対して流れ込さ 気流の方か流れ出る気流よりむ開瓜洞に近い效果宗 すことるわかる，第 13 図は AEDC の迮音速たデル

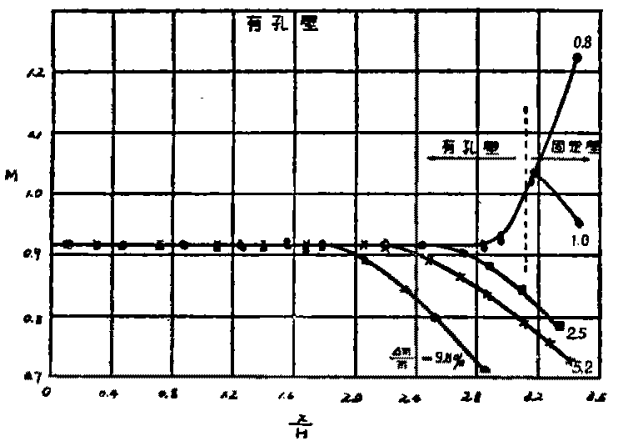

第 13 图 平行有孔壁の流出量に対する主流 に沿与 $M$ 数の分布

風洞で W. Chew が行った重験の結果を元するので

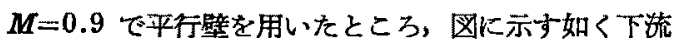
部分の速度が急に落らていることか明らかになった。

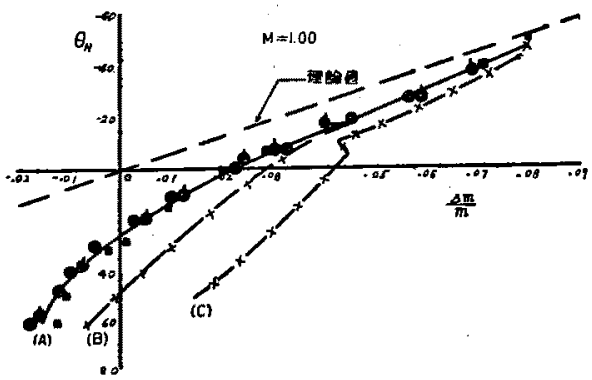

5 万丂至 33\%の open ratio

(A) small opening ratio

(B) medium opening ratio

(C) large opening ratio

第 14 図 $M=1.00$ に技りる種冬の有孔壁の 傾き角と流出量との関你

第 14 図は5ないし $33 \%$ open ratio を持つ壁に 傾き角をあたえて， suction の最との関係を調ぺたす

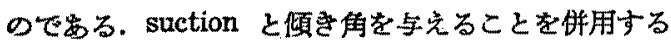
とよい結果か得られることがわかる. しか子 suction の量が比較的多い場合には理論健とよく合っている. suction の量が少い時には㜔界属の発達のために壁の 傾き俑は小さくてすむ. open ratio の大きい壁では

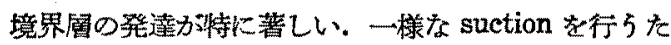
めに通風室を区切って，各函の中の圧力を装光る方法 は, 境目の所から攅乱か起るのでらまくない. C.A.L. の 21"x4” の小さい風洞では一様な porosity の壁 を用いて，かなり一様な超音速流を得ることがでさた が, 後でむっと大きな風洞で同じ open ratio の壁を 用いてやった所调膨脹か現われたのて，測定部の大口 の辺りの壁の porosity 变えて実駿行った. 測定 部で一様な $M$ 数分布を得るためには，大略測定部の 幅に等しい炕の辰さに亘って porosity を集えて分 布させることによって入口での過嘲脹とそれにとすな い $M$ 数分布か波を打つことをさけてやることが大切 でむる. AEDC の Gardenier と Chew が選音速模 刑風洞を用いて行った結果も同じよ5で，覀音速流は ほとんど問題はないが，超音速ノズルを用いないて有 孔壁だけを用いると一般に過膨脹が起ら， $M$ 数分布 が波を打つ.これを改良するためには上述のよらに測 定部への大口で porosity を制御することか必要であ る、最後に遥音擦風洞に括ける $M$ 数の決定の問题を 管えて見上5．亚音速の部分力等に達しでいる時には 通風室が模型を入れたための影㤰を受けるのだ，した がって模型前方の一様流るまた模型を入れたための変 動を受けると考文ねばならない，現在の所では模型を

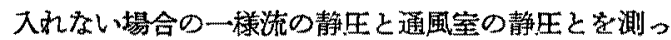
$\tau M$ 数の補正曲線画き，模型を入九た場合の $M$ 数 は通風室の静生を測ることによって決めることにして いる. 将来は干选のない場合の\&っと組織的で精確な 実験を多く行って，それらの data に基づて $M$ 数 の決定法も考文直されねばならないであろ5。

\section{4. 透音速風洞壁干涉の理諭}

透音速風洞の風洞壁を代表するるのとして有溝壁と

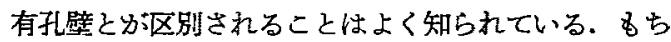
ろんその両者の中閒の性省を有するるのも無数に考充

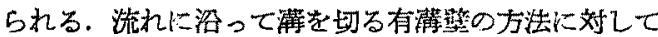
Busemann は境界条件を Homogeneous な形に与え ることを提案し

$$
\begin{gathered}
\Delta p=K \rho u_{0} \frac{\partial v}{\partial x} \quad \text { また } \quad \varphi_{x}+K_{\varphi_{x n}}=0 \\
K=-\frac{l}{\pi} \log \left[\sin \frac{\pi a}{2 l}\right]
\end{gathered}
$$

を与えた。ただし，lは满の中点間の距㒕， $a$ は㴖の

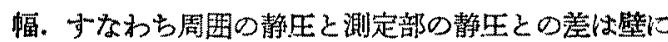
丟直な万向の速度成分の主流方向一の勾配に比例する

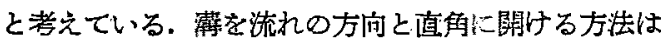


ブラウン大学の Maeder らによって行われ，この場 合には里力差は垂直速度成分に比例すると考穴るのが 、妥当である. 有孔壁すなわち壁に孔を開ける方法るし ばしば用いられこの場合にる，生力差は孔を過ぎる時 の粘性によって禹直漏洩速度に比例して釣合うとする のが普通である. すなわち Guderley, Maeder らの 有孔壁位対与境界条件は:

$$
v=R \frac{\Delta p}{\rho u_{0}} \text { 广をは } \frac{\partial \varphi}{\partial x}+\frac{1}{R} \frac{\partial \varphi}{\partial n}=0
$$

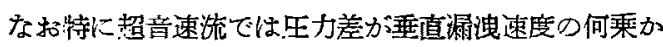
に比例すると考充た方がよいとるいわ机ている。いず れにしても壁を通って里力降下か存在するといらこと が重要でする。

実際の風洞ては上に述べた如く壁の形が周期的に雜 化するものを使うため:二次的な㻴乱か存在する可能 性がある.これについて線型理㝃による簡単な計算を

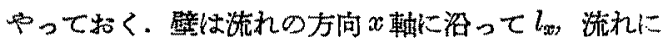
垂宜の方向 $y$ 軸に沿って $l_{y}$ なる周期を持つとする. ポテンシャルは周期的でないポテンシャル $\phi_{1}=$ $\phi_{1}(x y z)$ と周期的ポテンシャル

$$
\phi_{p}=\sum A_{m n} \sin \frac{n \pi x}{l_{w}} \sin \frac{n \pi y}{l_{y}} e^{-i_{m m} x}
$$

との和として表わされる. ここで

$$
\mu_{m n}=\sqrt{\left(1-M^{2}\right)\left(\frac{2 \pi n}{l_{n}}\right)^{2}+\left(\frac{2 \pi m}{l_{v}}\right)^{2}}
$$

でする. $M<1 な ら は ゙ ~ \mu_{m}$ は常に正の央数でするが， $M>1$ の封には

$$
\left(\frac{m}{l_{y}}\right)^{2} \nless\left(M^{2}-1\right)\left(\frac{n}{l_{x}}\right)^{2}
$$

ならば $\mu_{m n}$ は正の矣数ではない。このことは超音迢 流場では，周波数の高い,波肪残り得ること示してい， る.

さて次に亚音速における風洞効果の計算法を示す。 模型の代りに特異点を置いて，壁か存在するために付 加すべきホテンシャル申を線型理論によって求め， 次に模型の置かれた位置に沏引る ば，それか壁が存在するために誘起される干啮速度を 与える. фの中には壁の性資を決める slot factor = $K$ または porosity パラメターR が含まれているの で，壁の性筫と模型に及结す風洞效果とがこの上5に して結びつけられる. 有渾壁の場合の計算については D.D. Davis と O. Moore ${ }^{10)}$ が完全流体の式に基づいて 一栐に㴖が分布した円形風洞，上下の壁に一様に溝の 分布した短形風洞，円形風洞の結果を矩形断面に写像 して四周に满の分布した場合の禓力についての干涉， 二次元の場合などを計算している。巻末に補正最に する図表か驸いていて便利である. Mathews9性 lift (a) 因

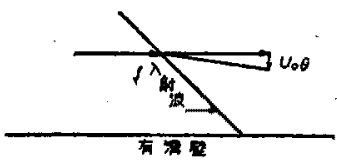

(b) 図

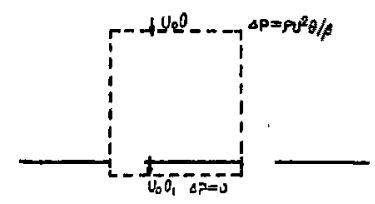

第 15 図 有灌壁で反射波を生じないた めの条件を求めるための図

interference の場合について境界条件を homogeneous にしないで葳密な阡算を行った。計算は相当蕧襍 であるがその結果によると㴖の数が 1 個とか 2 個の少 い場合を除いては homogeneous の境界条件を使って ほとんと同じ結果が得られる上5である. E.D. Kne-

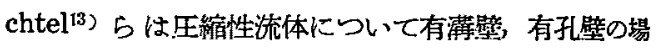
合を計算した. 抵抗物体の場合については数值計算の 結果が出ているが，有澅壁は D.D. Davis の結果飞 含まれ，有孔壁は Goodman 5（第28 図）の結果に 含まれるすのである. NACA Ames の Julian Allen そ J. M. Spiegel 怙有孔壁の場合には, Blockage と lift の干涉を零にする porosity バラメタの值は余り 異ならないが，有浶壁の場合にはかなり浶つ幅を変光 ねばならないことを指摘している。

超音速流では模型から出る波か壁にぶつかって反射 波を生で，再び模型に㴆ってくるといら形で風洞干啮 が表われる，入射波から充分下流を考えて反射波を消 すために必要な㴖の open ratio=。 を次のよ5にL て求めることができる. (b) 园に扎いて流れに垂直な 断面を考えると，入射波の後万では下问の速度 $U_{0} \theta$ と， 压力の上界 $\Delta p=\rho U^{2} \theta / \beta$ が生ずる.满を通って下向 の速度を $U_{0} \theta_{1}$ とすると連続の関保式

$$
\begin{aligned}
& \rho U_{0} \theta=\rho U_{0} \theta_{1} \sigma \\
\therefore \quad & \theta=\theta_{1} \sigma
\end{aligned}
$$

エネルギーの関係式

$$
\begin{aligned}
& \Delta p+\frac{1}{2} \rho\left(U_{0} \theta\right)^{2}=\frac{1}{2} \rho\left(U_{0} \theta_{1}\right)^{2} \\
& \therefore \quad \frac{\theta}{\beta}+\frac{1}{2} \theta^{2}=\frac{1}{2} \theta_{1}^{2}
\end{aligned}
$$

(1), (2)

$$
\sigma=\frac{\beta \theta}{2}\left(\frac{1}{1+\frac{\beta \theta}{2}}\right)
$$

上の結果から解るよらに一様流の $M$ 数と入射波の佰 
き角とによって open rato=。は它んぞれ異なった値 を要求される。一方 porous 壁で反射波を消すための 条件怯次のようにして求められる。般に大射波の5 しろで

$$
\begin{aligned}
\Delta p & =-\rho U_{0} \Delta u \\
-\Delta u & ==v \tan \theta
\end{aligned}
$$

が成立する。

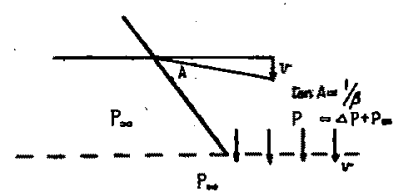

節 16 园有孔壁で反射波を生じないた めの条件を求めるための図

壁を過ぎって同じ值の速度 $v$ と王力至 $\Delta p$ とがあれ は波佉消える。すなわる

$$
R=\frac{\rho U_{0} v}{\Delta p}=\frac{\rho U_{0} v}{-\rho U_{0} \Delta u}=\frac{v}{-\Delta u}=\frac{1}{\tan A}=\beta
$$

$R=\beta$ なることが反射波を吸収するをめの条件であ る. 次に境界濖の影響を吟味するため簡単な計算を 行5.境界䚄を $M$ 数の異なる二つの相に置き換元 て，壁の porosity パラメタには境界層がない場合に 波が消える値を選んで置く，入射波の位置から始めて 順次特性曲線の方法で計算する．境界層に相当するM 数の小さい方の層か残っている限り反射波が出て一を ん壬力が下るが，速度の遅い方の層が全部壁の外に吹 き出されてしまうと王力は入射波直後の值まで回復す ろ. 第 17 図は計算値と理論值を比較したもので, 定 性的に理論か泟しいことを示している.この計算の結 果境界尿の存在のための生力の撜乱が相当遗くまで及 ぶことも明らかにされる。

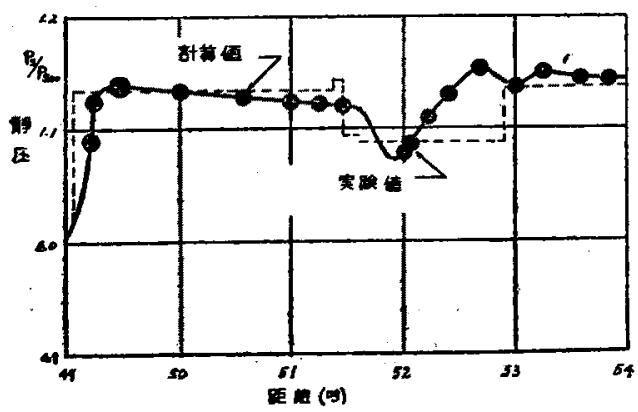

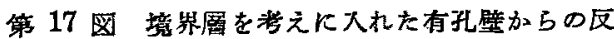
射波に上る壁加ら1咑源たった所の流九 の方闹の压力分布

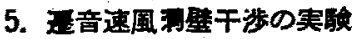

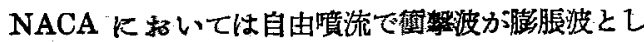

て反射し，固定㽝で王縮友として反射することから， その中間の性質を有孔壁行持たせることを計画した。 1949 年 3 月, ス ズルの contraction ratio 70:1 測 定断面積 $2 \frac{1}{2} \times 4$ 专 in の矩形風洞を用い，之の測定壁 の上下に平行な有孔壁として市肘の sintered bronze ( 0.005 in の径の粒子を加熱模合して 0.08 in の板厚 にしたるの）を取つけ，反射波の四收に関する実験汇

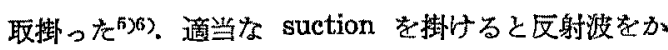
なりの程度に吸収することを確めだう。一方有薄壁に 対する反射波吸収の問題には疑問があったが，弾丸を 発射して有溝壁の間を通過せしめる万法で，境界層 がないので，反射波の吸収はできたといらことであ る. 次に WADC の $6 \times 6$ in の超音速風洞炕よて Goethert と Buekley が行った実跧を稆介する、M 数は 1.75 で, shock wave generator に上って二次 元の衝繋波を作り，壁から 1 in 離れた所に細い、針状

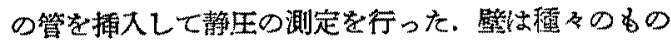
を簡単に公換できるようにし，また境界層の厚さを制 御するをめに通風窒で suction・を行った。第 18 図は open ratio を 10 ない乙 $40 \%$ K変えを場合の先験 で, open ratio が大きくなるにつれて王打が一たん 下る所か現われる。第 19 図は suction の量を加減し

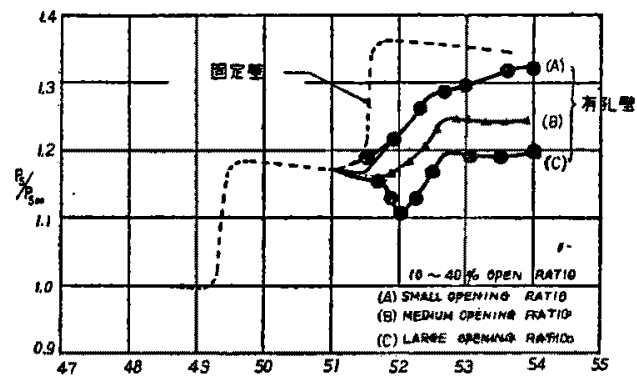

第 18 図－通風空と一㥞流の圧力司一に保って 㮔々の Open ratio の有孔壁による衙整 波の反射

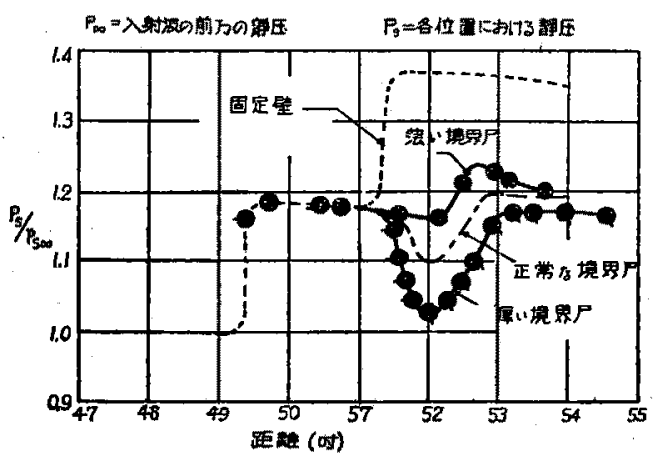

第 19 図境界層の厚さを变えた塂合の有孔壁加 らの行䡋波の反射 


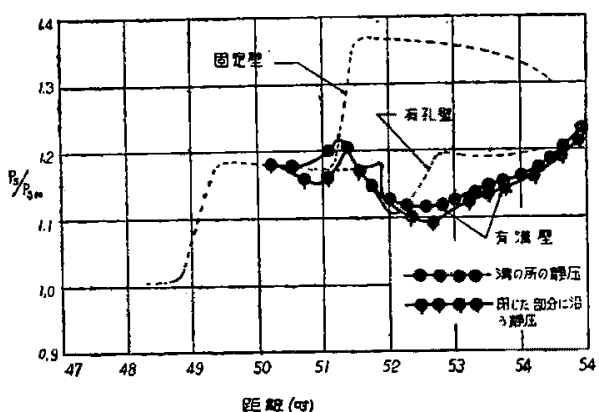

第 20 図 $M_{\infty}=1.75$ として有灌壁と有孔壁とによ る反射波の比較

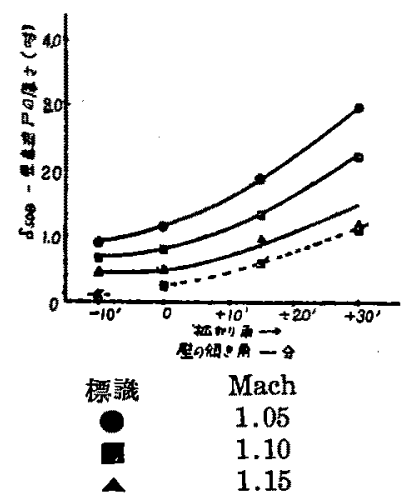

第 21 図 C.A.L. $3^{\prime} \times 4^{\prime}$ の有孔薙洞の測定部 に扣りる境界層の原さ

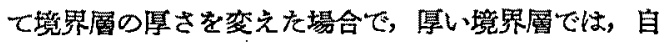
由噴流の場合のよ5に压力が一定値になる前に膨脹波 が出て生力があ所がある，境界層老薄くすると元来 閏じた部分が面皘より大きいのだ，今度は王力が

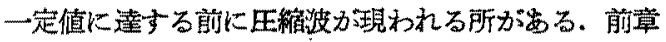
の理論計算にしたがって溝の数を9本として满幅を決

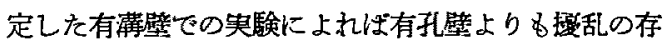
在する距離が長いことがわかる（第20図）、境界層を 薄くしてるこの傾向は改善されなかった. 境界層が㴟

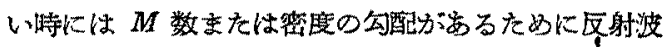
が出るがこのことよりる重要なのは，境界層の亜音

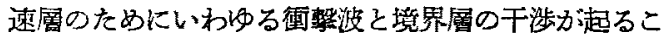
とである. 壁に孔を開けたりするので贯際に境界圈は

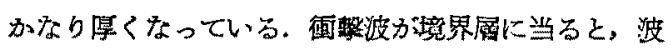
の大射した点上り前方に王力口上界が伝わり，境界

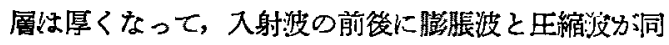
時に現われて，その婹乱は前後に遠くまで及ぶことに なる. 西音速の俤をでさるだけ薄くするためには suction 机えばよいが，一方壁を converge さ炕るこ とが必要である（第21図）. 有潅壁を用いた場合には 溝の部分と閶じた部分とで膨脹波と王縮波とがそれぞ
れ反射するので両者が混合して反射波は消えるよ5に 考えられるが，実際には医綰波と膨脹波厄反射角か浦

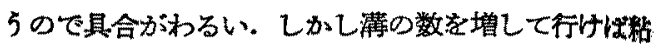
性の影響が刹いて，予期した如く反射波を吸収するこ とも可能である.第 22 図は有清壁と有孔壁について 横幅方向の線復度に対する授乱の大きさの変り方を示 したものである、第 23 図，第 24 罒に示す如く有孔

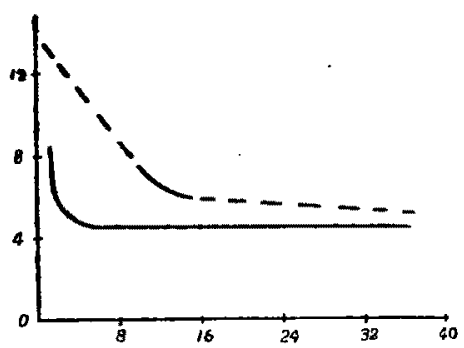

第 22 四酢または孔の線密度に奶子る反射 波の程校

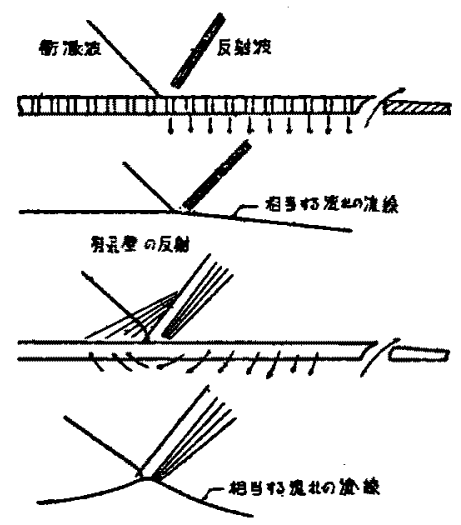

第 23 図 (上) 第 24 国有游壁心反期 (下)

壁においては括の孔の間の絽方向の流れは妨げられ

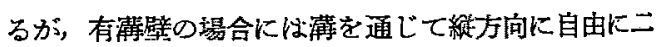
次的流れか誘毞されるので境界層の中の重音速渐の影

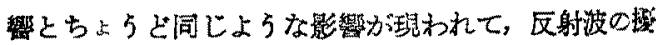
乱は有薄警の方がきいことになる。いずれにしても 有孔壁，有滦壁ともに境界層の亜音速流の部分のため に循骤流を生じて，理想的な反射波の昅収は实現され ない. つぎに1列として C.A.L. の有孔篦の風洞て blockage $0.96 \%$ およ゙ 1.2\%，先細比 12 の回転体の $M$ 数 0.98 に括ける王打分布の測定結果を Thompson"15による理諭值と比皎して見る. 第 25 四に示す 如く理諭は $M$ 数 1 に近い䓄厄適用するのがやや無理

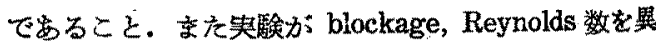
にしているにもかかからず三者とむかなりょく一效し ている. U A C で行われた $M$ 数 0.959 , 最大 block- 


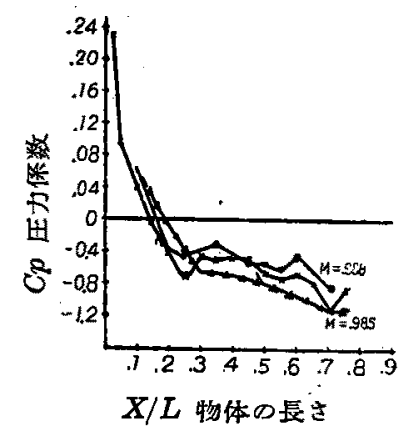

\begin{tabular}{|c|c|c|c|}
\hline & & $\begin{array}{c}\% \% \\
\text { Block }\end{array}$ & $\begin{array}{l}\mathbf{R N} \\
\times 106\end{array}$ \\
\hline - & $21 / 4^{\prime \prime} \times 4^{\prime \prime}$ 成洞 & 0.96 & 0.16 \\
\hline$x$ & $3^{\prime} \times 4^{\prime}$ 成洞 & 3.18 & 2,5 \\
\hline$\Delta$ & 理諭交䟩 25 & & \\
\hline
\end{tabular}

第 25 因 回転体の亜音速にむける王力分布

age $2.6 \%$ の実颣艺第 26 図に示す. Reynolds 数は 同一に保たれたか，図に示す如く blockage の道いに よる実験值の変化はない，C A L の回転体の実験に よると，壁の傾角を変えて，境界層の厚さを制御して やると，物体に沿与王力分布は変ってくるか，抵抗や モヌントには $1^{\circ}$ 以内の変化では住とんど影響がない。 この上5に三次元の物体に対してる二次元の実験とほ とんど同じょろなととがいえる. 超音速に猢りる射

\section{録}

(102面より䊏く)

\section{园 \\ 象}

16. 洞度天気国利用の試み $A$ test of the application of vorticity charts. F. Sanders \& E. Kessler. Bull. Amer. Met. Soc. 36, 6 (1955/6) 251-255

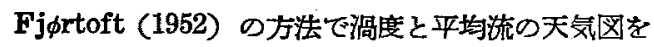
作った，1953 年の秋から初冬にかけて日ムの図につ いて瀜度の中心の速度と平均流の速度とを比皎した。 半分以上の場合には，中心の方向と平均流の方向とは

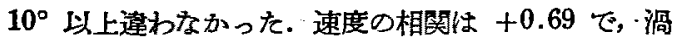

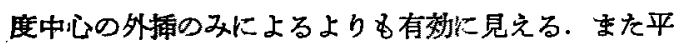
均流のすへてのリッジャトラフに Rossby の方程式を 当てはめると，平均流の场子外塖法以上に上く予報厄 きることがかかった.（大井正一）

17. シェット・ストリーム・ブロジット资数の 解析 Analysis of some "project jet stream." $\mathrm{H}$. Landers. Bull. Amer. Met. Soc. 36, 8 (1955/10),

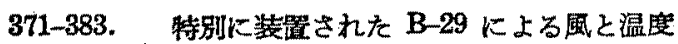
の料を，普通の上同風と気淈の資料と比較した. 2 組の垂直断面図と天気图を作り，風の婸の相造を論し
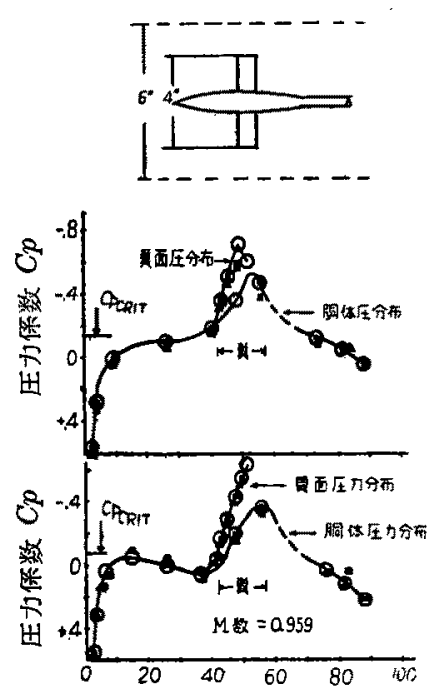

琶 $M_{\text {数 }}=0.959$

\begin{tabular}{|c|c|c|c|}
\hline 瑟誡 & 測定㸉面梦 & 全 & Blockage \\
\hline$\square$ & $6^{\prime \prime} \times 6^{\prime \prime}$ & $15^{\prime \prime}$ & $2.69 \%$ \\
\hline $\mathbf{A}$ & $6^{* \prime} \times 6.25^{\prime \prime}$ & $9^{\prime \prime}$ & $2.47 \%$ \\
\hline 0 & $A C 8-F t$ & & $0.014 \%$ \\
\hline
\end{tabular}

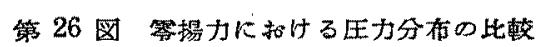
波の吸収に関してはやはり有孔壁の方か有㴖壁よりむ よいことがわがる。

（末 完）

た. 一らの場合，二つの方法によって得られた区奶符 号の渦度の場か洞し区域を占めていることが判った。 レーゥィンやパイボール資料に詨する地球曲率の補正 と，2 分閒平均法による誤差は反対等号を持ってい

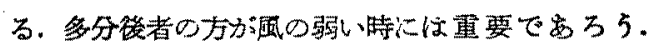
(大井正一)

18. 雷雨に伴う烈しい活流を予報する一方法 $A$ technique for predicting extreme turbulence related to thunderstorms. F.C. Bates. Bull. Amer. Met. Soc. 36, $8(1955 / 10) 379-383$. 長い閪畹雨 に乱流はつきむのとされ，雷零を突き技ける技術を持 ためパイロットは雷零を过回することが公理とされて いた：しかし最近はそ5でないとい5証贱が現われて

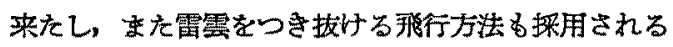
ようになった。したがって強い乱流があるよな区域 を知らせることか子予報者の任務となって来た. 1955年 7 月 1 日から extreme といら術語は“稀にしか出逢 わない，飛行機の操繸困難で，機体に損害があるかす 知れない”と定镜されることになった. extreme と いらことは地表付近に絶えず下向きのドラフトがする よ5な条件を指すのか潽通となった，筑密 (95 面へ緒く) 